\title{
Ali se z ustanovitvijo pokrajin upravni servis za državljane približuje ali oddaljuje
}

UDK: 353(497.4)

\author{
Tone Jerovšek \\ Univerza v Ljubljani, Fakulteta za upravo \\ tone.jerovsek@fu.uni-lj.si
}

\begin{abstract}
IZVLEČEK
Prispevek obravnava problematiko kvalitete zagotavljanja upravnih storitev po oblikovanju pokrajin. Sedanja dostopnost upravnih storitev $v$ upravnih enotah je zgledna. S tem je postavljen visok standard pokrajinam. Opozorjeno je na zakonsko preslabo definiran način identifikacije lokalne zadeve širšega pomena in nalog regionalnega pomena ter na neustreznost načina prevzema oziroma prenosa državnih nalog na pokrajino. To bi lahko povzročilo nejasna razmerja med državo, pokrajino in občinami. Kar pa bi imelo tudi neugodne posledice za izvajanje upravnih storitev, ki jih sedaj na pregleden in sorazmerno kvaliteten način zagotavljajo država oziroma občine. Preprečiti je treba, da bi se v pokrajinah vzpostavil birokratski odnos, saj presenetljivo po tem predlogu zakona država, kljub prenosu državnih nalog na pokrajino, nima nobenega vpliva na izvolitev oziroma imenovanje predsednika pokrajine, direktorja pokrajinske uprave in načelnikov pokrajinskih upravnih organov. Prispevek opozarja na potrebo postopnega prenašanja in prevzemanja regulatornih in izvršilnih nalog pokrajine, ki naj poteka hkrati $z$ uskladitvijo področne zakonodaje.
\end{abstract}

Ključne besede: regionalizacija, pokrajine, upravne storitve, upravni servis

To vprašanje je bistveno ob ustanavljanju pokrajin z več vidikov. Ali bo z oblikovanjem pokrajin in njenih izvirnih ter prenesenih državnih pristojnost vzpostavljen kakovostno ugodnejši dostop do upravnih storitev za stranke. Prav tako pa, ali bo z oblikovanjem pokrajin na področjih, ki jih bo pokrajina urejala in izvrševala, omogočen večji vpliv lokalnega okolja in s tem večji poudarek specifičnim potrebam ljudi na določenem pokrajinskem območju. Sedaj 
Tone Jerovšek

Ali se z ustanovitvijo pokrajin upravni

servis za državljane približuje ali oddaljuje

na državni regulativni in posledično izvršilni ravni ta interes ni mogel biti do te mere prisoten z vidika posebnih potreb in specifik posameznega okolja. To naj bi zagotovil Zakon o pokrajinah', po katerem pokrajina ureja zadeve iz svoje pristojnosti s svojimi predpisi $v$ skladu z določbami zakona, ki ureja lokalno samoupravo (4. člen). Po določbi 7. člena pa pokrajina samostojno ureja lokalne zadeve širšega pomena in z zakonom določene zadeve regionalnega pomena $v$ korist svojega prebivalstva. Tudi pri urejanju prenesenih državnih pristojnosti, če je tako določeno z zakonom ali uredbo vlade, lahko pokrajina ureja opravljanje posameznih nalog iz državne pristojnosti s svojimi predpisi (14. člen).

Pomembna okoliščina ob ustanavljanju pokrajin je tudi, kakšen bo organizacijski upravni servis pokrajine, da bi bile upravne storitve v pokrajinski upravi, bolj kot doslej pri upravnih enotah, dostopnejše fizičnim in pravnim osebam in njihovim specifičnim potrebam. Za opravljanje upravnih nalog iz svoje pristojnosti ustanovi pokrajina pokrajinsko upravo in pokrajinske upravne organe ter podeljuje javna pooblastila posameznikom in obstoječim pravnim osebam, ali pa $v$ skladu z zakonom ustanovi pravne osebe javnega prava, kot nosilce javnih pooblastil. Pokrajina zagotavlja izvajanje javnih služb iz svoje pristojnosti na način in $v$ oblikah, določenih z zakonom (8. člen). Pokrajina opravlja tudi posamezne izvršilne naloge iz državne pristojnosti, katerih opravljanje je nanjo prenesla država z zakonom. Vse to bo seveda opravljala, če bo imela ustrezne pristojnosti. Z vidika upravno organizacijskega izvajanja upravnih nalog zakon ne prinaša novosti.

Pač pa določbe predloga Zakona o pokrajinah kažejo na močno decentraliziran regulativni in upravno izvršilni koncept sedanjega državnega reguliranja in izvrševanja upravnih nalog, za razliko od sedaj relativno centraliziranega. Vendar pa nadaljnje proučevanje predloga zakona pokaže, da je zakon prav v ključnih določbah povsem splošen in deklarativen. Tako si ni mogoče predstavljati, kaj bo ob ustanovitvi pokrajin pokrajina lahko sploh opravljala. Določbe zakona na pokrajino neposredno ne prenašajo nobenih pristojnosti. To je razvidno iz posameznih določb, saj zakon naloge pokrajin ureja samo $v$ treh členih, ti pa so tako splošni, da nobene naloge ni mogoče prevzeti na pokrajino brez uskladitve

1 Zakon je v fazi predloga predložila Vlada RS Državnemu zboru. Tu uporabljeno besedilo je $z$ njegove spletne strani. 
področnega zakona ali s sprejetjem posebnega zakona, kar zakon tudi sam določa $\vee$ vseh treh pristojnostnih členih ${ }^{2}$ oziroma $\vee 66$. členu. ${ }^{3}$

Vse svoje naloge naj bi pokrajina opravljala kot:

- lokalne zadeve širšega pomena,

- naloge regionalnega pomena in

- prenesene državne naloge.

Glede lokalnih zadev širšega pomena je določeno, da jih pokrajina samostojno ureja in določi s svojim predpisom, ali so določene z zakonom. Lokalne zadeve širšega pomena, so zlasti naloge:

- zagotavljanja javnih gospodarskih služb pokrajinskega pomena,

- zagotavljanja javnih negospodarskih služb pokrajinskega pomena in

- zagotavljanje z zakonom določenih nalog občin ter lokalnih javnih gospodarskih in negospodarskih služb, ki so skupne območjem več občin (12. člen).

Zakon $v$ tem delu ni natančen, ker ne pove, kaj šteti za gospodarske in negospodarske javne službe pokrajinskega pomena $v$ razmerju do republiških javnih gospodarskih služb. Opredelitev je torej odvisna od zakonskega urejanja in določanja, kaj so po sprejemu Zakona o pokrajinah republiške gospodarske in negospodarske javne službe. Sama zakonska določba je zgolj deklarativne narave. Izvedbeno pa ne pove skoraj nič. To se kaže kot slabost pri razmejevanju pristojnosti države in pokrajine na področju javnih služb. Tako moramo

2 Gre za člene 12,13 in 14.

3 66. člen:

(1) Prenos pristojnosti na pokrajine na področjih iz 12., 13. in prvega odstavka 14. člena tega zakona se izvede najpozneje do 31. decembra $2007 \mathrm{z}$ uskladitvijo zakonov, ki urejajo zadeve na teh področjih, s tem zakonom.

(2) Če uskladitev iz prejšnjega odstavka ni opravljena, se prenos pristojnosti izvede s posebnim zakonom, ki začne veljati 1. januarja 2009.

(3) Ministrstva, pristojna za posamezno področje nalog iz drugega odstavka 14. člena tega zakona, morajo dve leti po ustanovitvi pokrajinskih uprav spremljati njihovo delo in na podlagi analize najpozneje $v$ treh letih predlagati rešitve glede prenosa izvrševanja nalog iz državne pristojnosti, ki jih izvršujejo upravne enote, na pokrajine.

(4) Z zakoni iz prvega in drugega odstavka tega člena se določijo stvarno premoženje in ustanoviteljske pravice države ter pravice iz naslova lastnine, ki se s 1. januarjem 2009 prenesejo na pokrajine. Finančne obveznosti državnega proračuna, prevzete do dne prenosa, se ne prenašajo na pokrajine.

(5) Pokrajine s 1. januarjem 2009 vstopijo v koncesijske in druge pogodbe, sklenjene za izvajanje javnih služb, opravljanje nalog $v$ javno korist, posebne pravice na javnem dobru ter izkoriščanje naravnega bogastva iz pokrajinske pristojnosti. 
Tone Jerovšek

Ali se z ustanovitvijo pokrajin upravni

servis za državljane približuje ali oddaljuje

do ustreznih sprememb posameznih zakonov, ki urejajo gospodarske in negospodarske javne službe, šteti, da na tem področju zakon ne prinaša nobenih novosti. Zakon torej ni izvedbeno uporaben, ker ne omogoča izvedbo uvodne določbe 12. člena, da pokrajina samostojno ureja lokalne zadeve širšega pomena, ki jih določi s svojim predpisom, ker ni kriterijev za razmejevanje.

Zakon predvideva tudi prevzem nekaterih občinskih nalog na pokrajino, kar je prepuščeno ustreznemu usklajevanju med občinami. To so to zadeve širšega pomena ( iz tretje alineje drugega odstavka 12. člena) za zagotavljanje z zakonom določenih nalog občin ter lokalnih javnih gospodarskih in negospodarskih javnih služb, ki so skupne območjem več občin. Vendar je izvedba tega prevzema oziroma prenosa prepuščena posplošeni nadaljnji izvedbeni določbi, ki pravi, da se s predpisom, s katerim se določijo te naloge pokrajin, določijo občine na območje katerih se naloge nanašajo, če občine s tem soglašajo. Tu ni niti jasno, za čigav predpis gre, za občinski o prenosu teh nalog ali za pokrajinski o njihovem prevzemu. Vsekakor pa soglasje občin terja določeno usklajevanje interesov in šele posledično prevzem uslužbencev. Vse je torej prepuščeno zahtevnemu usklajevanju med občinami ali nadaljnjemu zakonskemu urejanju in zapletom, ki lahko iz tega nastanejo zaradi pomanjkanja zakonskih kriterijev.

Glede nalog regionalnega pomena je rečeno, da pokrajina opravlja naloge regionalnega pomena, ki se določijo z zakonom, in sicer $v$ zvezi s tem, da 13. člen:

1. določa cilje regionalnega razvoja in zagotavlja skladen razvoj celotnega območja pokrajine ter zagotavlja koherentnost oblikovanja regionalnih razvojnih politik s Strategijo razvoja Slovenije, sprejema regionalni razvojni program in ukrepe za izvajanje regionalnega razvojnega programa;

2. sprejema prostorske akte za načrtovanje prostorskih ureditev regionalnega pomena;

3. sprejema načrte razvoja prometnega sistema v pokrajini in izvaja programe ukrepov na področju cestnega prometa, gradi in vzdržuje pokrajinske ceste, določa prometno ureditev na pokrajinskih cestah in površinah za mirujoči promet pokrajinskega pomena, izvaja naloge preventive in vzgoje $v$ cestnem prometu, ter ureja plovbo na celinskih vodah; 
4. sprejema programe razvoja gospodarstva, načrtuje politiko spodbujanja razvoja turizma in zagotavlja izvajanje ukrepov za spodbujanje podjetništva in turizma;

5. sprejema energetski koncept pokrajine, koordinira lokalne energetske koncepte in izvaja programe uveljavljanja obnovljivih virov energije in učinkovite rabe energije;

6. sodeluje pri načrtovanju strukturne kmetijske politike in izvaja ukrepe državnih pomoči regionalnega pomena ter sodeluje pri pripravi programa za razvoj podeželja in ribištva;

7. sprejema stanovanjski program za izvajanje stanovanjske politike regionalnega pomena, zagotavlja sredstva za graditev, pridobitev in oddajanje neprofitnih stanovanj in stanovanjskih stavb ter ustanovi pokrajinski stanovanjski sklad;

8. izvaja zemljiško politiko regionalnega pomena;

9. sprejema in izvaja programe varstva okolja, varstva naravnih vrednot in programe upravljanja voda za izvajanje gospodarske javne službe upravljanja voda ter sprejema ukrepe varstva narave;

10. sprejema programe razvoja visokega šolstva in raziskav regionalnega pomena;

11. sprejema in izvaja regionalne programe razvoja šolstva in športa ter na posameznih področjih vzgoje in izobraževanja ter športa določa izvajalce programov, ustanavlja in financira vzgojne izobraževalne zavode ter zavode s področja športa;

12. sprejema in izvaja program zdravstvenega varstva, ustanavlja javne bolnišnice regionalnega pomena in zagotavlja njihovo mrežo na območju pokrajine, sprejema programe na področju preprečevanja uporabe prepovedanih drog in obravnave uživalcev prepovedanih drog, programe njihovega zdravljenja in socialne rehabilitacije, zagotavlja izvajanje ukrepov na področju javnega zdravja, usklajuje nujno medicinsko pomoč, zagotavlja izvajanje specialističnega zdravljenja, ustanovi svet za zdravje in zavod za zdravstveno varstvo;

13. načrtuje in organizira socialnovarstvene storitve in programe s področja dela, družine in socialnega varstva, in sicer: socialno preventivo, prvo socialno pomoč, osebno pomoč in pomoč družini na domu, institucionalno varstvo odraslih s posebnimi potrebami in starejših oseb, storitev varstvo, vodenje in zaposlitev pod posebnimi pogoji, organizira varstvo otrok, prikrajšanih za normalno družinsko življenje, ter zagotavlja 
Tone Jerovšek

\section{Ali se $z$ ustanovitvijo pokrajin upravni \\ servis za državljane približuje ali oddaljuje}

svetovanje in organiziranje pomoči posameznikom s težavami $v$ duševnem zdravju, žrtvam nasilja, odraslim s posebnimi potrebami, osebam z različnimi oblikami zasvojenosti, storilcem kaznivih dejanj; skupaj z državo soustanovi center za socialno delo in zagotavlja dejavnost centrov za socialno delo na svojem območju ter zagotavlja pravico do izbire družinskega pomočnika;

14. sprejema programe razvoja kulturnih dejavnosti in izvaja ukrepe za zagotavljanje javnega interesa za kulturo, zagotavlja naloge območnih knjižnic, regionalne naloge sklada za kulturne dejavnosti in ustanavlja javne zavode na področju kulture (pokrajinski arhivi, muzeji in galerije, poklicna gledališča, restavratorska središča, zavod za upravljanje dediščine in spomenikov);

15. sprejema programe in izvaja ukrepe zaščite in reševanja, usmerja osebno in vzajemno zaščito $z$ organiziranjem svetovalne službe, določa posebne ukrepe varstva pred požarom ter razglaša povečano požarno ogroženost in zagotavlja prenos opozoril, napotil ali prepovedi prebivalstvu med povečano požarno ogroženostjo in ob velikih požarih, organizira, opremlja in vodi sile za zaščito, ocenjuje ogroženost zaradi naravnih in drugih nesreč na območju pokrajine ter načrtuje izvajanje zaščite, reševanja in pomoči ob nesrečah, reševanje in pomoč ob naravnih in drugih nesrečah ter ocenjuje škodo, ki jo povzročijo naravne in druge nesreče, sprejme z zakonom določene ukrepe za varstvo pred utopitvami;

16. načrtuje in izvaja ukrepe za integracijo tujcev in beguncev, zagotavlja mrežo pomoči pri integraciji;

17. ureja in opravlja druge naloge regionalnega pomena, ki se določijo z zakonom.

Tudi v tem členu je zakon pretežno operativno neizvedljiv, ker je določeno, da pokrajina opravlja naloge regionalnega pomena, ki se določijo z zakonom. $V$ zvezi s tem pa ima pokrajina navedene pristojnosti oziroma pooblastila. Če analiziramo eno samo pristojnost iz 2. točke 17. člena, ki določa, da pokrajina sprejema prostorske akte za načrtovanje prostorskih ureditev regionalnega pomena, se pokaže naslednji problem. Dokler ni spremenjen Zakon o urejanju prostora, ki razmejuje pristojnost glede prostorskih aktov med državo in občino, si ni mogoče zamisliti izvajanja te določbe, ker bi prihajalo do kompetenčnega spora med pokrajino in državo ali občino. Zakon namreč ne pove, $v$ 
katerem delu oziroma glede katerih prostorskih aktov preide prostorsko urejanje na pokrajino. Tako se pokaže kot nerealna določba 66. člena, da se prenos pristojnosti na pokrajine na področjih iz 13. člena tega zakona izvede najpozneje do 31. decembra 2007 z uskladitvijo zakonov, ki urejajo zadeve na teh področjih, s tem zakonom. Rok je nerealen, saj gre za obsežne regulativne spremembe, ki bodo na ravni zakonskega urejanja $v$ državnem zboru in izvedbenih predpisov vlade in ministrstev zahtevna naloga, ki bo vzela veliko več časa, kakor ga je predvidenega. Tu namreč ne gre samo za prenos pristojnosti. Dosedanja razmejitev pristojnosti med državo in občinami bo terjala tudi drugačno ureditev nekaterih vsebinskih razmerij, če omenimo samo prostorsko zakonodajo. $V$ ta čas pa pade še predsedovanje Evropski uniji.

Še bolj neizvedljiva se zdi določba drugega odstavka 66. člena, ki določa: "če uskladitev ni opravljena, se prenos pristojnosti izvede s posebnim zakonom, ki začne veljati 1. januarja 2009. "Seveda si je vsebino takšnega zakona, ki naj bi bil z vidika razmejitve pristojnosti na posameznih področjih izvedljiv, težko predstavljati. Vsaka od naštetih točk 13. člena, ki naj bi se poslej štele za naloge regionalnega pomena, našteva vrsto pravno urejenih področij z zakoni in podzakonskimi predpisi, ki urejajo materialna razmerja, pristojnosti, organizacijo služb, načine delovanja. Vse to je treba urediti in razmejiti v razmerju do države in občin. Sicer bi lahko nastala organizacijska, pristojnostna in vsakršna zmeda. Določbe, ki nasploh govorijo o sprejemanju programov in načrtov, pa so neizvedljive, ne da bi upoštevali njihovo ureditev po področni zakonodaji.

Tudi glede prenesenih državnih nalog zakon neposredno ne prenaša izvrševanja teh iz državne pristojnosti na pokrajino. Našteva le področja na katerih mora biti izveden prenos z zakonom. To so:

- upravne naloge s področja gospodarstva, turizma in gostinstva, kmetijstva, razlastitev in služnosti v javnem interesu, upravnih dovoljenj za poseganje $\vee$ prostor, graditev in uporabo zgrajenih objektov ter vodenja registrov na stanovanjskem področju;

- naloge gradbenih inšpektorjev;

- naloge inšpekcijskega nadzora na področju cest, ki jim zakon, ki ureja javne ceste, daje regionalni pomen (14. člen).

Sam prenos pa se opravi z zakonom, s področnim materialnim oziroma organizacijskim zakonom, ki ureja katero od naštetih področij (npr. z ZUreP glede razlastitev ali z ZGO glede gradbenih dovoljenj in nalog gradbenih 
Tone Jerovšek

Ali se z ustanovitvijo pokrajin upravni

servis za državljane približuje ali oddaljuje

inšpektorjev). Sama ustanovitev pokrajin in vzpostavitev organov pokrajine, vključno s pokrajinsko upravo, še ne pomeni prevzema teh nalog. Zakon bolj na zalogo našteva področja in naloge prenosa, zato je vprašljivo, ali se bo tak prenos dejansko tudi uresničil, ko se bodo usklajevali posamezni področni zakoni in se bo pokazala vsa problematika uskladitve in prenosov od države in občine na pokrajino. Slednji na večini omenjenih področjih urejata in izvršujeta te naloge. Tudi si ni mogoče zamisliti, kako prestavljati posamezne upravne delavce iz upravnih enot na pokrajino oziroma na katera vrata organizacijskih enot upravne enote nabiti tablo "pokrajinska uprava«. Če na tem mestu odpremo samo vprašanje gradbene inšpekcije in inšpekcijskega nadzora na področju cest, ki preide na pokrajino, medtem ko vse druge inšpekcije ostanejo kot organi $v$ sestavi posameznih ministrstev. Vemo pa, da nezakonit poseg $v$ prostor ne zadeva samo gradbene inšpekcije. Seveda se ob tem poraja dvom v ustreznost prenosa gradbene inšpekcij na pokrajino, ki bo že itak izdajala gradbena dovoljenja, nato pa se bo še sama inšpicirala z vidika zakonitosti posegov $\checkmark$ prostor. Gre za vprašanje neodvisnosti inšpekcije, ki se je pokazala v sedanji ureditvi, ko so inšpekcije kot organi $v$ sestavi ministrstev ločene od prvega upravnega nivoja, za zelo ustrezno in učinkovito ureditev. Onemogočala je namreč odvisnost inšpektorjev od lokalnega okolja, v katerem se opravlja. Če je lahko nadzor na področju cest regionalnega pomena vendarle pokrajinski, ker gre za interese regionalnega pomena, pa je nadzor nad posegi v prostor vsedržavnega pomena, ker gre za pomembne javne interese, ki jih mora zaščititi država, ker se nanašajo na podobo krajine, urbanizma, naravne in z delom pridobljene kulturne dediščine itd. Te pa bo država lahko ustrezno ščitila le $s$ postavitvijo povsem neodvisne institucionalne inšpekcije, ki ne bo odvisna od lokalnega okolja. Zato se je bati lokalnih pritiskov na inšpekcijo in posledično opustitev dolžnega ukrepanja. Le če bo prišlo pri posegih $v$ prostor do pritožbe zoper posamičen upravni akt inšpekcije, je $\vee 44$. členu zakona predvideno, da o pritožbah zoper posamične upravne akte pokrajinskih upravnih organov in nosilcev pokrajinskih javnih pooblastil iz prenesene državne pristojnosti odločajo stvarno pristojna ministrstva. Določeno je tudi, da morajo direktor pokrajinske uprave in načelniki pokrajinskih upravnih organov, ki opravljajo prenesene državne naloge, ravnati $v$ skladu $z$ obveznimi navodili in nalogi ministrov, pristojnih za področja, na katera spadajo prenesene državne naloge. Vendar je mogoče kontrolo izvajanja takih navodil $v$ konkretnem upravnem odločanju izvajati predvsem, če se odpravijo in razveljavijo konkretne upravne 
odločbe po nadzorstveni pravici po 276. členu Zakona o splošnem upravnem postopku - ZUP. Vendar je nadzorstvena pravica redko uporabljena in največkrat prepozna, ker se za nezakonitosti ni vedelo. Pokrajinska inšpekcija bo glede prenesenih nalog inšpekcijskega nadzora iz državne pristojnosti odgovarjala za svoje delo direktorju pokrajinske uprave in preko njega predsedniku pokrajine. Inšpekcija bo statusno upravni organ pokrajine. Taka ureditev pa kaže na pretirano povezanost odločanja in nadzora ter imenovanj, vse na istem nivoju, kar ne bo zagotavljalo neodvisnosti inšpekcije.

$\checkmark$ zakonu je povsem nerazumljiva ureditev drugega odstavka 14. člena $v$ razmerju do prvega odstavka. $V$ slednjem zakon našteva zgoraj navedene upravne naloge iz državne pristojnosti, ki se z uskladitvijo področne zakonodaje prenesejo $\vee$ izvrševanje pokrajini. $\vee$ drugem odstavku pa določa, da pokrajina opravlja tudi naloge, ki jih izvršujejo upravne enote na njenem območju in druge naloge iz državne pristojnosti, ki ji jih z zakonom prenese država $v$ izvrševanje. Ni jasno, zakaj je treba $\vee$ prvih treh točkah prvega odstavka 14. člena naštevati določene naloge oziroma področja, ki se spet določijo z zakonom, če je predviden prenos vseh pristojnosti upravnih enot in še drugih pristojnosti države na pokrajino. Vprašanje je, kdaj naj bi se to zgodilo in kakšna je statusna oziroma organizacijska usoda upravnih enot in kdaj naj bi pokrajina prevzela vse njihove naloge. Ali po prevzemu vseh nalog postanejo upravne enote izpostave pokrajinske uprave oziroma pokrajinskih upravnih organov, ni jasno. V tretjem odstavku 66. člena je sicer določba, po kateri morajo ministrstva, pristojna za posamezno področje nalog iz drugega odstavka 14. člena tega zakona, dve leti po ustanovitvi pokrajinskih uprav spremljati njihovo delo in na podlagi analize najpozneje $\vee$ treh letih predlagati rešitve glede prenosa izvrševanja nalog iz državne pristojnosti, ki jih izvršujejo upravne enote, na pokrajine. S prenosom upravnih nalog iz državne pristojnosti iz prve, druge in tretje točke prvega odstavka 14. člena naj bi pokrajina očitno dobila nekaj pristojnosti za začetek delovanja. Vendar se zdi, da so našteta področja, ki bodo z zakonom prenesena na pokrajino, prav neposrečeno izbrana. Delitev omenjenih nalog na tiste, ki se prenesejo na pokrajino do konca leta 2007 in jih ta začne opravljati s prenosom, ozirom če ustrezni področni zakoni do tega roka ne bodo usklajeni, se te naloge prenesejo s posebnim tehničnim zakonom do 1.1.2009 in jih $\mathrm{s}$ tem datumom začne pokrajina tudi opravljati, in na ostale naloge, ki naj se prenesejo na pokrajino $v$ treh letih, je vsebinsko povsem neproučena. Ni pojasnjeno, zakaj bi, kot določa 66. člen, morala ministrstva pristojna za posamezno po- 
Tone Jerovšek

Ali se z ustanovitvijo pokrajin upravni

servis za državljane približuje ali oddaljuje

dročje, samo za naloge iz drugega odstavka 14. člena tega zakona, ki jih prav tako izvršujejo upravne enote ali ministrstva ali njihovi organi v sestavi, dve leti po ustanovitvi pokrajinskih uprav spremljati njihovo delo in na podlagi analize najpozneje $\vee$ treh letih predlagati rešitve glede prenosa izvrševanja nalog iz državne pristojnosti na pokrajine. Nobene potrebe po časovni diferenciaciji glede prenosa nalog ni, ker mora tak prenos temeljiti na spremembi področne zakonodaje za vsako od naštetih nalog. Menimo, da tudi glede prenesenih državnih nalog ne pride $v$ poštev tehnični zakon, če uskladitev področne zakonodaje $\vee$ predvidenem roku ni opravljena, ker tak zakon tega prenosa ne more ustrezno uresničiti.

Predvidena ureditev poraja vrsto vprašanj, ki v predlogu zakona nimajo odgovora. $\vee$ obrazložitvi je problem prenosa preveč poenostavljen in nekritično prikazan. Obrazložitev pravi:»S prvim odstavkom 14. člena je določeno, da pokrajina opravlja naloge iz državne pristojnosti, določene z zakonom, ki se nanašajo na del upravnih nalog, ki jih sedaj opravljajo upravne enote in resorna ministrstva ter naloge inšpekcijskega nadzora na področjih, ki se nanašajo na naloge regionalnega pomena, za katere so pristojne pokrajine. $\vee$ drugem odstavku pa je določeno, da pokrajina izvršuje naloge iz državne pristojnosti, za katere so sedaj pristojne upravne enote in druge naloge, ki jih nanjo prenese država. To so lahko na primer odločitve iz pristojnosti vlade (podeljevanje koncesij za izkoriščanje naravnih surovin ipd.), naloge odločanja $v$ upravnih stvareh, ki jih na prvi stopnji opravljajo organi v sestavi ministrstev, ministrstva sama ali pa zoper odločitve ministrstev ni pritožbe. Obe določbi sta povezani s prehodno določbo 66. člena, ki določa, da začno pokrajine opravljati naloge iz prvega odstavka 1. januarja 2009 (op. p. obrazložitev ni točna. Opravljati jih začnejo s prenosom, to je s sprejemom zakona o uskladitvi. Le če do uskladitve s področnim zakonom ne pride pa s 1. januarjem 2009). Prenos nalog iz drugega odstavka pa se bo opravil (op. p. prav tako kot prenos nalog iz prvega odstavka) s področnimi zakoni v skladu z rešitvami, ki jih bodo predlagala pristojna ministrstva po dvoletnem spremljanju dela pokrajinskih uprav na podlagi analize dela pokrajinskih uprav, praviloma v treh letih."

«Določba 66. člena ureja roke za prenos pristojnosti na pokrajine z zakoni, ki urejajo posamezna področja nalog ter prenos teh nalog $\vee$ pristojnost pokrajin $s$ posebnim zakonom, če s področnimi zakoni to ne bo opravljeno $v$ določenem roku, ureditev premoženjskih razmerij ob prenosu nalog. Stvarno premoženje države, ustanoviteljske pravice in pravice iz naslova lastnine $v$ osebah javnega 
prava, ustanovljenih za izvajanje nalog, prenesenih $\vee$ pristojnost pokrajin, je treba urediti $\vee$ zakonih, ki urejajo prenos nalog in sicer tako, da pokrajine te pravice, proste finančnih bremen, dobijo s 1.1.2009. S tem datumom vstopijo pokrajine $v$ koncesijske in druge pogodbe, sklenjene za izvajanje javnih služb in drugih nalog $v$ javno korist in za pridobitev posebne pravice na javnem dobru. $S$ tretjim odstavkom pa je določen način izvedbe postopnega prenosa nalog iz državne pristojnosti, ki jih opravljajo upravne enote, na pokrajine ter okvirni roki. Ministrstva so, vsako na svojem področju, zadolžena za dvoletno spremljanje dela pokrajinskih uprav. Na podlagi spremljanja morajo $v$ treh letih pripraviti analize ter glede na ugotovitve predlagati rešitve glede prenosa nalog pokrajinam v izvrševanje. "Seveda prenos in prevzem pristojnosti na pokrajino ne bo tako preprost in enostaven, ker je zaklavzuliran z uskladitveno zakonodajo o prenosu.

\section{Časovna dimenzija prenosa nalog}

V štirih členih (66., 67., 69.in 70.) sta bili brez vsake vsebinske analize posameznih področij razrešeni vsebinska vzpostavitev druge ravni lokalne samouprave in organizacija upravnega pokrajinskega podsistema $v$ razmerju do države in občin. Če se želi doseči postopnost prenosa, kar je edino realna možnost, jo bo zagotovilo usklajevanje področne zakonodaje, ki do konca leta 2007 nikakor ne more biti sprejeta. Tehnični zakon, ki bi samo naštel področja prenosa pristojnosti, pa menimo, da ni sprejemljiv in izvedljiv, ker bo povzročil preveč pravnih praznin. Gre vendarle za več kot samo za prenos pristojnosti, saj si bo te pokrajina najprej delila z upravnimi enotami in ministrstvi, nato pa, če bi pokrajina prevzela vse upravne naloge upravnih enot, z ministrstvi. Šele vsebinska razprava o uskladitvi vsakega področnega predpisa, s katerim se izvede prenos pristojnosti, bo pokazala vsebinske, organizacijske, tehnične in časovne možnosti prenosa nalog in posledično prevzema javnih uslužbencev na pokrajino.

Zato se tudi določba 67. člena predloga zakona, ki govori o zagotovitvi pogojev za začetek dela pokrajin, zdi preveč poenostavljena. Glasi se: " Vlada z uredbo določi ukrepe za zagotovitev kadrovskih, prostorskih in drugih pogojev za začetek delovanja pokrajin. Na podlagi te uredbe se zagotovita izvedba postopkov konstituiranja pokrajin in začasno opravljanje upravnih nalog iz pristojnosti pokrajin. «V 69. členu pa je določeno: "Javne uslužbence, zaposlene v 
Tone Jerovšek

\section{Ali se $z$ ustanovitvijo pokrajin upravni}

servis za državljane približuje ali oddaljuje

organih državne uprave, ki so do začetka dela pokrajin opravljali naloge, ki so prešle $v$ pristojnost pokrajin, prevzamejo pokrajine $v$ pokrajinske uprave, najpozneje $v$ 60 dneh po sprejetju odloka o ustanovitvi pokrajinske uprave. Javne uslužbence, zaposlene $v$ občinskih upravah občin z območja pokrajine, ki so do začetka dela pokrajin opravljali naloge, ki so prešle $\vee$ pristojnost pokrajin, prevzamejo pokrajine $\vee$ pokrajinske uprave, najpozneje $\vee 60$ dneh po sprejetju predpisa iz tretjega odstavka 12. člena tega zakona. «" Tako prenos nalog kakor tudi prevzem delavcev bi moral biti sočasen z uskladitvijo področnih zakonov. Šele takrat se bo vedelo, katere javne uslužbence bo prevzela pokrajina in kateri ostanejo na dosedanjih delovnih mestih. Zelo problematično bi bilo, če bi proces transformacije sedaj zgledno delujočih upravnih enot in večinoma tudi občinskih uprav potekal nenadzorovano, stranke pa ne bi mogle uveljavljati svojih pravic $v$ sedaj utečenih postopkih. Ob teh določbah se je bati nekontrolirane erozije upravnih enot in nekaterih drugih državnih organov, npr. inšpekcij.

$\mathrm{Na}$ uvodoma zastavljeno vprašanje, ali se upravni servis za stranke z ustanovitvijo pokrajin približuje ali oddaljuje, še ni mogoče dati odgovora. Na podlagi zgoraj povedanega lahko zaključimo, da je ta proces po omenjenih določbah preveč nejasen in ne daje zagotovil za bolj učinkovit upravni servis od sedanjega. Da ta proces ne bi potekal stihijsko, bi bilo treba naloge države in občin na pokrajino prevzemati oziroma prenašati postopno, izključno po uskladitvi področne zakonodaje, brez vnaprejšnjih terminov, še najmanj pa s tehničnih zakonom o prenosu pristojnosti, ki bi začel veljati s 1. januarjem 2009. Pri usklajevanju zakonodaje pa je treba zagotoviti to kar določa 14. člen predloga zakona, po katerem mora pokrajina zagotoviti opravljanje prenesenih nalog iz državne pristojnosti na način, s katerim se za prebivalce ne bo zmanjšala dostopnost do upravnih storitev. Sedanja dostopnost upravnih storitev $v$ upravnih enotah je zgledna. S tem je postavljen visok standard pokrajinam. Preprečiti je treba, da bi se $v$ pokrajinah vzpostavil birokratski odnos, saj presenetljivo, da po tem predlogu zakona država kljub prenosu državnih nalog na pokrajino, nima nobenega vpliva na izvolitev oziroma imenovanje predsednika

4 Tretja alineja in tretji odstavek 12. člena se glasita:

zagotavljanje z zakonom določenih nalog občin ter lokalnih javnih gospodarskih in negospodarskih služb, ki so skupne območjem več občin.

(3) S predpisom, s katerim se določijo naloge pokrajine iz tretje alineje prejšnjega odstavka tega člena, se določijo občine, na območje katerih se naloge nanašajo, če občine s tem soglašajo. 
Tone Jerovšek

Ali se z ustanovitvijo pokrajin upravni servis za državljane približuje ali oddaljuje

pokrajine, direktorja pokrajinske uprave in načelnikov pokrajinskih upravnih organov, ki bodo del njenih naloge urejali in izvrševali. To pa je že drugo vprašanje za posebno razpravo.

Dr. Anton Jerovšek je diplomiral in magistriral na Pravni fakulteti v Ljubljani in nato doktoriral s temo disertacije Pravnomočnost dokončnih upravnih aktov. Zaposlitve: pripravnik v Skupščini SRS, nato pripravnik na Okrožnem sodišču v Ljubljani, referent, svetovalec, samostojni svetovalec Skupščine SRS v Zakonodajnopravni komisiji, sekretar Zbora občin Skupščine SRS, sodnik Vrhovnega sodišča SRS, predsednik Zakonodajnopravne komisije Skupščine SRS, sodnik Ustavnega sodišča SRS in Republike Slovenije, od leta 1994 do 1996 predsednik Ustavnega sodišča Republike Slovenije, od leta 1998 do 2000 izredni profesor na Pravni fakulteti in Visoki upravni šoli Univerze $v$ Ljubljani, leta 2000 minister za zakonodajo $v$ Vladi Republike Slovenije in od leta 2000 dalje izredni profesor na Fakulteti za upravo in Pravni fakulteti Univerze v Ljubljani. 
Tone Jerovšek

Ali se z ustanovitvijo pokrajin upravni

servis za državljane približuje ali oddaljuje

\section{SUMMARY}

\section{DOES THE ESTABLISHMENT OF REGIONS MAKE THE ADIMINISTRATIVE SERVICES MORE OR LESS ACCESSIBLE TO CITIZENS?}

The article deals with the issues of the quality of ensuring administrative services after the establishment of regions. An important issue regarding the establishment of regions is how the administrative service of the region will be organized if it is to make the administrative services at the regional administration more accessible to natural and legal persons and their specific needs than they used to be until now at the administrative units. From the point of view of the administrative and organizational execution of administrative tasks the law brings nothing new. The provisions in the proposed Regions Act suggest a heavily decentralized concept of the existing state-regulated and state-executed administrative tasks in terms of regulation and execution, as opposed to the current relatively centralized one. However, further study of the proposed act shows that the act is utterly general and declarative in its key provisions. The provisions of the act do not transfer any competence to the region directly. The tasks of the region are stipulated in three articles of the act only, and these are so general that no task can be transferred to the region without the harmonization with the sectoral law or without adopting a separate law, as is also stipulated in the act.

The article points out that the act does not define well enough how local matters of wider importance and tasks of regional importance should be identified; it also points out that the way tasks are transferred from the state to the region is inadequate. This could lead to unclear relations between the state, the region and municipalities, which makes the delimitation of competence between the state and the region more difficult. The act provides for the transfer of some of the municipal tasks to the region; the transfer itself is left to the coordination between municipalities. It is not clear whose regulation this is: is it a case of municipalities transferring the tasks or is it the region assuming the tasks? So all of this is left to a demanding coordination between municipalities or further regulation and ensuing complications due to lack of legal criteria. 
Regarding the tasks of regional importance the act is operationally mostly not feasible because it is stipulated that the region performs the tasks of regional importance as specified by law. The act also does not say in which part, or rather, for which spatial acts planning is transferred to the region. The existing delimitation of competence between the state and the municipalities will also call for a different regulation of some of the substantive relations, e.g. spatial legislation. This also coincides with the period of the Slovene EU Presidency. Each of the above-mentioned items, which should be tasks of regional importance from now on, is followed by a list of regulated areas with laws and implementing regulations regulating material relations, competence, organization of services, ways of operating. All of this has to be regulated and delimited in relation to the state and municipalities, otherwise there could arise confusion as to organization, competence and the like. The general provisions on the adoption of programmes and plans are not feasible without taking into account their regulation as specified by sectoral legislation.

As far as the transferred state tasks go the act again does not transfer the execution of these tasks directly from the state to the region, but only lists areas where the transfer should be stipulated by law. The establishment of regions and regional bodies, including the regional administration, does not imply the assumption of these tasks. It seems that the act enumerates areas and tasks to be transferred just in case, so it is questionable whether this kind of transfer will actually take place when individual sectoral laws will be harmonized and the whole issue of harmonization and transfers from the state and municipalities to the region will become evident. Control over spatial interventions is of national importance because this constitutes an important public interest which should be protected by the state since it involves landscape character, town planning, natural and cultural heritage etc. The state can effectively protect these only by establishing an institutional inspectorate entirely independent of the local community. The way things are it may well be feared that the inspectorate will be subjected to pressure from the local community resulting in a failure to take the necessary measures.

Regarding the tasks of inspectorate control transferred from the state, the regional inspectorate will answer to the director of the regional administration and through him to the regional president. The inspectorate will be a regional administrative body by status. Such a set-up suggests too close a relationship between decision-making, control and appointments 
Tone Jerovšek

Ali se $z$ ustanovitvijo pokrajin upravni

servis za državljane približuje ali oddaljuje

- everything taking place on the same level - which will not ensure the independence of the inspectorate. It seems that the above-mentioned areas transferred to the region by law are not very aptly chosen. There is no need for a timeline for the transfer of the tasks since the transfer should be based on changing the sectoral legislation for each of the listed tasks.

If the goal is to achieve a gradual transfer, which is the only realistic option, the sectoral legislation needs to be harmonized, but this legislation can by no means be adopted by the end of 2007. A technical law only enumerating the areas of the transfer of competence is not acceptable and not feasible because it would produce too many legal gaps. This is more than just a transfer of competence. The region will first share the competence with the administrative units and ministries and then with the ministries if the region assumes all the administrative tasks of the administrative units. Only a discussion about the content of the harmonization of individual sectoral regulations used to execute the transfer of competence will show the possibilities of the transfer of the tasks and consequently of public servants to the region in terms of the content, organization, technical solutions and time. The transfer of tasks and employees should take place at the same time as the harmonization of the sectoral laws. That is when it will become clear which public servants will be transferred to the region and which will keep their previous posts. It would be highly problematic if the process of transformation of the now well-operating administrative units and in most part also municipal administrations took place in an uncontrolled way and causing that clients could not exercise their rights in now smooth-running procedures. There is a fear that these provisions will cause an uncontrolled erosion of administrative units and some other state bodies, e.g. inspectorates.

It is still not possible to answer the question whether the establishment of regions makes the administrative service more or less accessible to citizens. Based on the above, it can be concluded that this process as stipulated in the above-mentioned provisions is far too unclear and does not guarantee a more efficient administrative service than the existing one. The harmonization of legislation should ensure that which is stipulated in Article 14 of the proposed Act, namely that the region must ensure the performance of the transferred tasks from the state in a way that administrative services remain as accessible to citizens as they were before. The existing accessibility of administrative services at the administrative 

servis za državljane približuje ali oddaljuje

units is fairly good. They have set high standards to the regions. Bureaucratic red tape must be prevented, yet surprisingly, according to the proposed Act despite the transfer of the state tasks to the region the state has no influence on the appointment of those who will perform part of its tasks, i.e. the regional president, the director of the regional administration or the chiefs of the regional administrative bodies. 